\title{
Application of Entrepreneurial Marketing in Micro, Small and Medium Enterprise in Dhaulagiri, Nepal
}

\author{
Shrijan Gyanwali, Chanchai Bunchapattanasakda \\ School of Management, Shinawatra University, Bangkok, Thailand \\ Email: gyanwalishrijan@gmail.com, chanchai@siu.ac.th
}

How to cite this paper: Gyanwali, S. and Bunchapattanasakda, C. (2019) Application of Entrepreneurial Marketing in Micro, Small and Medium Enterprise in Dhaulagiri, Nepal. Open Journal of Business and Management, 7, 693-708.

https://doi.org/10.4236/ojbm.2019.72047

Received: February 22, 2019

Accepted: April 5, 2019

Published: April 8, 2019

Copyright () 2019 by author(s) and Scientific Research Publishing Inc. This work is licensed under the Creative Commons Attribution International License (CC BY 4.0).

http://creativecommons.org/licenses/by/4.0/

\begin{abstract}
Entrepreneurial marketing in Micro, Small and Medium Enterprise (MSME) considers more the firms unique business environment with entrepreneurs' innovative, proactive and opportunistic way of operation. MSME marketing practices and decision making seems more creative, alternative, instinctive, informal, unstructured, chaotic, and unplanned. Conducting marketing in small business is different than in large organization because multinationals do not have the resource constraints that small businesses have. The objective of study was to examine the relationship between entrepreneurial marketing dimensions and MSME performance measures, and to identify the best ways for MSME growth. Primary data were collected from 98 entrepreneurs in Parbat, Baglung and Myagdi Districts of Dhaulagiri Zone, Nepal. The quantitative analysis was made by Chi-square test, ANOVA analysis and correlation assessment to test hypotheses and examine the significant relationship between variables. Qualitative data were collected from ten experts and experienced personalities from government executives, entrepreneurs and business association executives. The research identified the significant relationship between entrepreneurial marketing and performance of MSME in Nepal. The qualitative study found that MSMEs have limited facilities from government and they have lacking enterprise friendly environment. It is suggested that Nepal government should introduce effective programs to motivate youths for establishing their enterprise so that income generation and employment opportunity will be generated. Five dimensions of entrepreneurial marketing named customer, market, entrepreneurial, innovation and influence orientations are recommended for further study.
\end{abstract}

\section{Keywords}

Entrepreneurial Marketing Dimensions, MSME, Performance Measures 


\section{Background}

Entrepreneurs and MSME owners need a better understanding of their marketing in order to address the challenges of this new world. Marketing is essential to provide customers what they need and want. Conducting marketing in small business is different than in large organization because multinationals do not have the resource constraints that small businesses have. Nevertheless, small business can capitalize on having flexibility to adopt changing market conditions which is lacking in larger organization with rigid hierarchical structures [1]. Marketing capability is defined as the ability of an organization to understand and fulfill customers' need at the right time, right place and right cost. Effective marketing attempt is essential for sustainable business performance [2].

MSME marketing considers more the firms unique business environment, characteristics of owner and managers, and available resources. The management culture is more innovative and MSME entrepreneurs tend to be more proactive and opportunistic in nature. MSME marketing practices and decision making seems more creative, alternative, instinctive, informal and unstructured, chaotic and unplanned. MSME entrepreneurial marketing process includes two major aspects as networking and word-of-mouth communication. Networking for business activities means that companies join together with a common objective, working together and cooperation through sharing ideas, knowledge, resources and technology. Such networking occurs, for example, through trade events and personal contact. Word-of-mouth communication is found more effective to MSME for internal and external relationship building, establishing mutual trust and developing listening skills and empathy. Entrepreneurial marketing relies heavily on word-of-mouth communication to develop customers through recommendation. These recommendations can occur from customers, suppliers or other referral groups. Word-of-mouth communication in MSME is exchange of ideas, brand image and such other elements of product or services through person to person interaction and oral discussion. Word-of-mouth is meaningful especially to purchase decision in many customers and B2B markets [3].

\section{Statement of Problem}

All the elements influencing for performance have no constant impact as their dynamism is being changed continuously and they are situational variables. Hence, no one can predict easily and accurately the success and long-term sustainability of any organization at present competitive and unstable business environment. However, the positive relationship between entrepreneurial orientation with performance in several different cultural and operational environments has been reported [4]. MSMEs, usually operated under the entrepreneurs' control, may suffer through the lack of knowledge and understanding of marketing planning and practices. It may result to the inadequate marketing and leading towards business failure. Therefore, it is essential to increase awareness 
of small firm to the importance of marketing [5]. The impact of competition in the business environment has compelled many organizations to turn around and start scanning the environment for information, so as to have competitive edge over other similar organization within the industry. Organizations have to maintain efficient and effective marketing intelligence in order to maintain their completive position in the industry [6]. Due to the lack of educational opportunities and poor support mechanism of state, Nepalese MSMEs are not able to sell their product/services to target customers. Therefore, the research and dissemination of knowledge on entrepreneurial marketing is essential in Nepal.

\section{Significance of the Study}

Marketing plans and activities in small and medium enterprise are influenced by entrepreneurial qualities. Although the research on entrepreneurial marketing is 30 years old, many important questions still are waiting for an answer. Whereas research now emphasizes entrepreneurial marketing techniques in MSME, there can be significant differences in the application of marketing in entrepreneurial-led and non-entrepreneurial-led firms [7] [8]. Entrepreneurial marketing dimensions named proactiveness, calculated risk taking, opportunity focus, innovative, resource leverage, customer intensity and value catenation that are to be internalized and applied effectively in marketing activities [9].

Survival and growth of MSME in the global competitive business environment is not easy because they generally have limitation of financial, human and technological resources. The entrepreneur alone takes major decisions of business and operational activities. Therefore, the success of enterprise depends upon the entrepreneur's creativity, innovation on product/service and process, risk taking capacity, identification of opportunity, proactiveness, relationship with customers and other stakeholders, effective utilization of resources, persuading to concern authority, marketing intelligence generation and communication, willingness to change, and inner motivation for achievement.

The study on MSME entrepreneurial marketing is needed in Nepal because such work has not done yet. The findings of such work would be applied in MSME operational activities for their growth. The policy makers will be able to consider the importance of entrepreneurial marketing while planning the MSME development activities. The academician will be benefited for their knowledge development and then conducting the further research.

\section{Objectives of the Study}

To assess the relationship between entrepreneurial marketing and MSME performance.

To evaluate the existing MSME marketing practice in Nepal.

To identify the better ways to improve the MSME development and their sustainability. 


\section{Conceptual Framework}

On the basis of review of past studies, the conceptual framework is developed. Dependent variable is MSME Performance where as independent variable comprises the four dimensions of entrepreneurial marketing named customer orientation, entrepreneurial orientation, market orientation and innovation orientation [10]. These four dimensions have some specific components. Customer orientation includes responsiveness, customer intensity and customer value creation. Similarly, market orientation includes resource leverage, networking/ relationship and market intelligence generation. Entrepreneurial orientation includes four elements named calculated risk taking, proactiveness, opportunity focus and willingness to change were as innovation orientation retains two elements as overarching knowledge and encouraging innovation. The conceptual framework is presented in Figure 1.

\section{Research Hypothesis}

Four alternative hypotheses relating to entrepreneurial marketing dimensions are set for testing by quantitative measures. These are presented as following:

$\mathrm{HO}_{1}$ Customer orientation has no significant effect on MSME performance.

$\mathrm{H}_{1}$ Customer orientation has significant effect on MSME performance.

$\mathrm{HO}_{2}$ Market orientation has no significant effect on MSME performance.

$\mathrm{H}_{2}$ Market orientation has Significant Effect on MSME Performance.

$\mathrm{HO}_{3}$ There is no significant relationship between entrepreneurial orientation and MSME performance.

$\mathrm{H}_{3}$ There is significant relationship between entrepreneurial orientation and MSME performance.

$\mathrm{HO}_{4}$ Innovation orientation has no significant effect on MSME performance.

$\mathrm{H}_{4}$ Innovation orientation has significant effect on MSME performance.

\section{Study Area}

Dhaulagiri Zone is situated in Northern part of western Nepal. It includes four districts of Province number four of the country. Out of four districts of Dhaulagiri Zone, three districts named Parbat, Baglung and Myagdi are choose for the

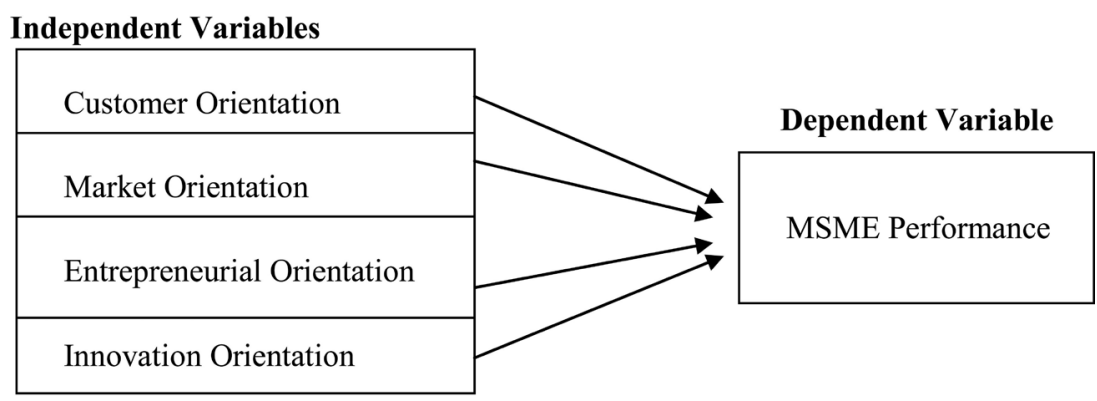

Source: Developed on the basis of existing models, Jones and Rowley (2011), and Morris, Schindehutte and LaForge (2002).

Figure 1. Conceptual framework. 
study. Parbat district covers 494 square kilometer space with total population 146,590. Baglung District has total population 268,937 and it covers 1784 square kilometer space where as Myagdi District comprises total population 113,641 and it covers 2297 square kilometer space [11] [12] [13] [14].

\section{Literature Review}

MSMEs have been contributing significantly for economic development and creating the employment opportunity. Small and medium enterprises are becoming main sources of employment and competitiveness creating entrepreneurial spirit and innovation. Small and medium enterprises that are driven by limited resources in finance, knowledge, information, time and opportunities do practice simple version of marketing [15]. Large companies competing through mass production, product differentiation and economic scales are being shifted to small enterprises relaying on knowledge, initiative and flexibility [16]. As compared to large firms, MSMEs are more reluctant to adopt a marketing approach mainly because of lack of resources and skills. MSME entrepreneurs are the sole decision makers of marketing programs on the basis of their experience and expectation of the consequences as they would not pose specialized knowledge on this field [17].

The survival of organizations depends on innovation, creativity and entrepreneurship in today's competitive world [18]. Those firms with a stronger entrepreneurial orientation have better performance than their counterparts in the same industry [19]. Similarly, some factors such as rapid advances in science and technology and more competitiveness in the business environment and also increasingly changing environment has caused company managers to consider the improvement of performance, entrepreneurial orientation and market orientation as an important goal [20].

Seven underlined dimensions of entrepreneurial marketing are presented as proactiveness, calculated risk taking, innovativeness, an opportunity focus, resource leveraging, customer intensity and value creation [21]. Further, a model of SME Entrepreneurial Marketing Orientation with four dimensions was introduced [10]. These four dimensions of entrepreneurial marketing dimensions are customer orientation (CO), entrepreneurial orientation (EO), innovation orientation (IO) and market orientation (MO) as shown in Figure 2.

Empirical review on entrepreneurial marketing and MSME performance shows their significant relationship in multidimensional perspective. Achieving growth in small business is not straightforward. The small businesses are operated in their own context with the combination of external environment, internal environment and owner-managers. Therefore, favorable internal and external environment, growing nature of business, and owner-manager's preparedness affect the business performance. These factors are affected by the strategies SMEs implement to grow the business [22]. Previously, companies were able to sell what produced, and their sales strategies were successful enough to increase their sales. 


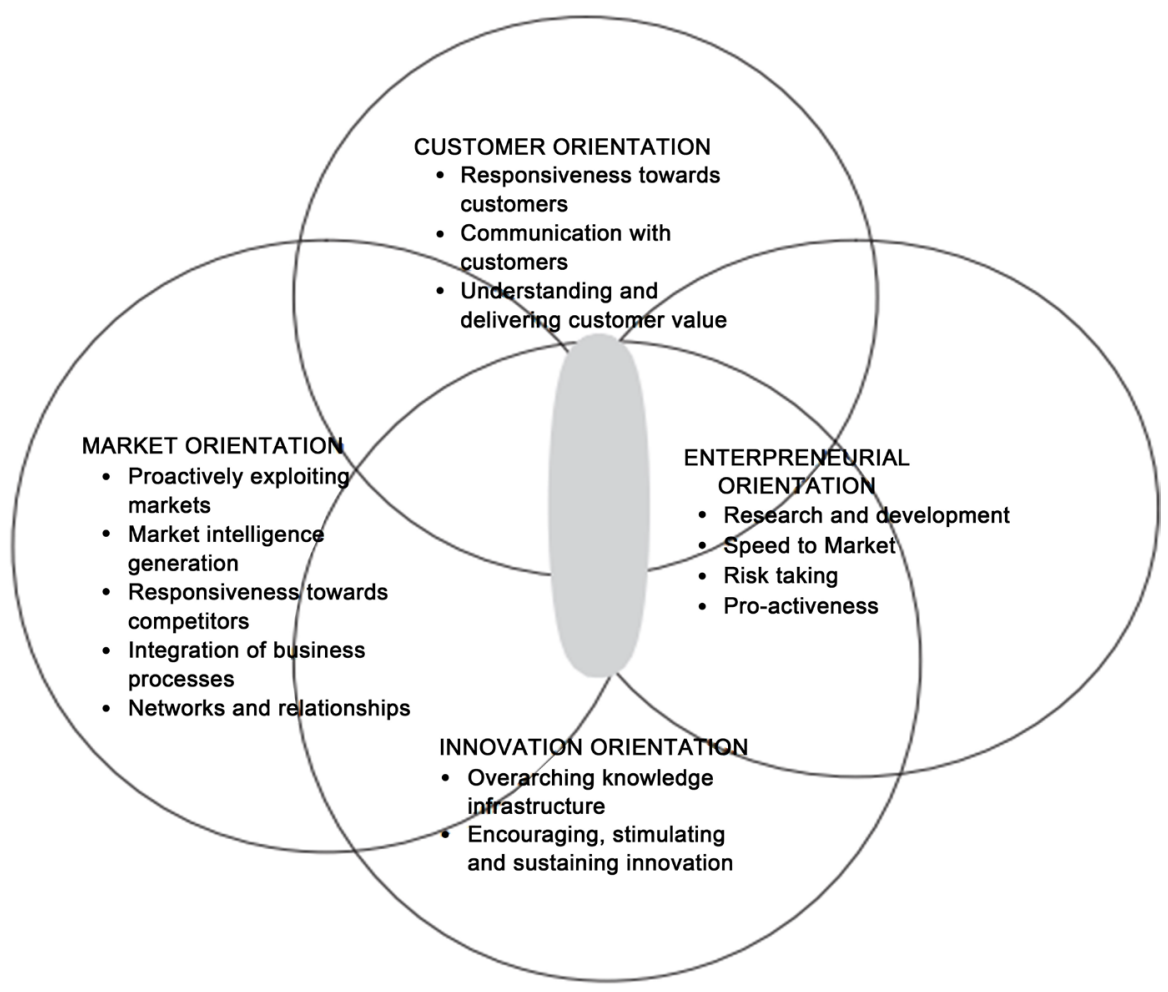

Source: Jones and Rowley (2011).

Figure 2. Model of SME entrepreneurial marketing orientation.

However these practices are increasing rendered inefficient as a customer-based marketing approach has replaced this prevailing approach. Marketing has become importance since it allows the companies to understand customers' need, the satisfaction of whom is pivotal for their financial success. Marketing strategies of many micro enterprises are not planned systematically or they do very limited marketing activities [2].

Marketing process in entrepreneurial marketing do not follow traditional marketing mix variable of price, place, promotion and product but instead entrepreneurial marketers need to related continuously with the market, their vision and customer preference present in their minds, constantly thinking of how to improve customer value. The firm had sufficient understanding of their target buyers and was thus able to create superior value for them continuously. This kept clients satisfied and warded off competition. The firms need to take leverage on resources by strategic alliance to be able to grow and they should take risk of introducing new products which need to go hand in hand with a market research [23].

Two dimensions of entrepreneurial orientation named autonomy and competitiveness were identified as influencing factors to business performance of handicrafts business in Nepal, whereas five dimensions (innovativeness, risk-taking, proactivenss, autonomy and competitive aggressiveness) and three dimensions of performance (efficiency, growth and profit) were analyzed by regression and correlation [24]. 
Nepalese society is traditional where overwhelming majority of women still is involved in the household activities as they are expected to do so in most of the families. Adult men are supposed to earn for the living and support their wives, children and ageing parents. Hence, Nepalese women are not much in the workforce and business. However, their role in agriculture is really valuable. They work hard, especially in village in their farm which does not give them a direct return such as wages and salaries [25].

Six dimensions of entrepreneurial marketing variables as growth orientation, opportunity orientation, customer focus, value creation through networks, informal marketing analysis and closeness to the market were proposed on the basis of literature review and having confirmatory factor analysis [26]. Entrepreneurship Development Institute of India (EDI) identified 13 entrepreneurial competencies as initiative, see and act on opportunities, persistence, information seeking, concern for high quality work, commitment to work contract, efficiency orientation, systematic planning, problem solving, self-confidence, assertiveness, persuasion and use of influence strategies which are critical for an enterprise to become competitive in the global world [27].

Two entrepreneurs rarely act the same, they may be engaged in the same business environment because they perceive, interpret and identify different possibilities, the space in which they take action may be completely different. Strategic orientation, commitment to seize opportunity, opportunity reorganization mechanism, control of resources and management structure are key difference between administrative marketing and entrepreneurial marketing attention. They also encouraged further research in entrepreneurial marketing and its use and impact on firms in all contexts [28].

Entrepreneurial marketing is creative attempt to address the unpredictable market situation. In this regard, innovation and industrial policies are fundamental in shifting the innovation path towards a more inclusive trajectorydetermining the structure of prices, factor costs, infrastructure and the availability of alternative technologies (and the knowledge that firms have about these technologies) - all affecting firms' investment decisions on their choice of technology [29]. According to the traditional model of organizational climate, organizational climate is the outcome of mainly three elements named organizational factor (structure, system, size and history), people factor (skills, personalities and age) and environmental factors (sociological, political, economic and technological factors). Organizational climate affect the individual behavior which has impact on organizational performance [30].

\section{Research Methodology}

A mixed method of research design with quantitative and qualitative data analysis was adopted. The total population of study was 3000 MSMEs who were associated with district chamber of commerce and industry in Parbat, Baglung and Myagdi. One hundred entrepreneurs were selected for quantitative data collec- 
tion from simple random technique. However, ninety-eight respondents returned the filled-up questionnaire and remaining two entrepreneurs were not available in their enterprise during revisit to collect the filled-up questionnaire. Ten experts and experienced personalities in the study area were chosen from government authorities, business association and entrepreneurs for qualitative data and their name was coded with different identification to maintain the confidentiality as accordance to standard practice of research work. For example, their identity was coded as entrepreneurs A, government executive $\mathrm{A}$, business association executive A, B, C, and so on. Structured questionnaire with five point Likert scale was used to collect the quantitative data whereas a check list of open ended questions was used to conduct the in-depth interview to collect the qualitative data. The analysis of quantitative data was made by hypothesis test and correlation analysis. Hypothesis test was made by Chi-square statistics and ANOVA test with help of SPSS. Content analysis was made for qualitative data.

\section{Analysis of Quantitative Data}

Quantitative analysis has been done to test the hypothesis and to examine the relationship between performance (dependent) variables and entrepreneurial marketing (independent) variables.

\subsection{Test of Hypotheses}

Entrepreneurs' demographic information (gender and nature of enterprise) and their response on 36 statements relating to entrepreneurial marketing have been examined to test the hypothesis. Enterprises are categorized in eight types as production, energy, agro/forestry, mining, IT/communication, tourism, construction and service according to their nature [12]. Four hypotheses relating to customer orientation (responsiveness, customer intensity and customer value creation), market orientation (resource leverage, networking/relationship and market intelligence generation), entrepreneurial orientation (calculated risk taking, proactiveness, opportunity focus and willingness to change) and innovation orientation (overarching learning and encouraging innovation) have been tested by Chi-square Statistics (Table 1) and ANOVA analysis (Table 2).

$\mathrm{H}_{1}$ Customer orientation has significant effect on MSME performance.

Table 1. Chi-square test.

\begin{tabular}{cccc}
\hline & \multicolumn{2}{c}{ Chi-square P Value } & \\
Entrepreneurial Marketing Dimensions & Fender & Nature of Firm & \\
\cline { 2 - 3 } Customer Orientation & $0.013^{*}$ & 0.053 & 98 \\
Market Orientation & 0.283 & $0.001^{* *}$ & 98 \\
Entrepreneurial Orientation & 0.814 & 0.827 & 98 \\
Innovation Orientation & 0.691 & 0.077 & 98 \\
\hline
\end{tabular}

Note: ${ }^{\star} \mathrm{P}$ Value $\leq 0.05 ;{ }^{*} \mathrm{P}$ Value $\leq 0.01$ 
Table 2. ANOVA Test.

\begin{tabular}{ccccc}
\hline \multirow{2}{*}{ Entrepreneurial Marketing Dimensions } & \multicolumn{2}{c}{ Gender } & \multicolumn{2}{c}{ Nature of Enterprise } \\
\cline { 2 - 5 } & $\mathrm{F}$ & Sig. & $\mathrm{F}$ & Sig. \\
\hline Market Orientation & 7.273 & $0.008^{\star *}$ & 2.305 & $0.033^{\star}$ \\
Innovation Orientation & 7.005 & $0.010^{\star *}$ & 2.337 & $0.031^{\star}$ \\
Entrepreneurial Orientation & 6.749 & $0.011^{*}$ & 1.665 & 0.128 \\
Customer Orientation & 5.518 & $0.021^{\star}$ & 1.316 & 0.252 \\
\hline
\end{tabular}

Note: ${ }^{\star} \mathrm{P}$ Value $\leq 0.05 ;{ }^{*} \mathrm{P}$ Value $\leq 0.01 ; \mathrm{N}=98$

$\mathrm{H}_{2}$ Market orientation has significant effect on MSME performance.

$\mathrm{H}_{3}$ There is significant relationship between entrepreneurial orientation and MSME performance.

$\mathrm{H}_{4}$ Innovation orientation has significant effect on MSME performance.

Table 1 shows that the relationship between gender and customer orientation is significant with P Value 0.013. Similarly, there is highly significant relationship between market orientation and nature of enterprise with P Value 0.001 . However, entrepreneurial orientation has no significant relationship with gender (P Value 0.814) and nature of firm (P Value 0.827). Innovation orientation has also no significant relationship with gender (P Value 0.691) and nature of firm (P Value 0.077) According to the Chi-square test, $\mathrm{H}_{1}$ and $\mathrm{H}_{2}$ are accepted and $\mathrm{H}_{3}$ and $\mathrm{H}_{4}$ are rejected.

Table 2 shows that market orientation and innovation orientation has highly significant association with gender (P Value 0.008 and 0.010 respectively). Similarly, market orientation and innovation orientation has significant association with nature of enterprise (P Value 0.033 and 0.031 respectively). While examining the entrepreneurial orientation and customer orientation, significant relationship has been found with gender ( $\mathrm{P}$ Value 0.011 and 0.021 respectively) whereas the relationship of entrepreneurial orientation and customer orientation to nature of enterprise has no significance ( $\mathrm{P}$ Value 0.128 and 0.252 respectively). According to the ANOVA analysis, all of the alternative hypotheses $\left(\mathrm{H}_{1}, \mathrm{H}_{2}\right.$, $\mathrm{H}_{3}$ and $\mathrm{H}_{4}$ ) are accepted.

\subsection{Correlation of Performance Measures with Entrepreneurial Dimensions}

The correlation between performance measures (goal achievement, owner/customer/staff/Suppliers satisfaction, market growth, effectiveness of product/service and work efficiency, and relevance of overall activities) and entrepreneurial dimensions (customer orientation, market orientation, entrepreneurial orientation and innovation) is evaluated and it is presented in Table 3.

Table 3 shows that all entrepreneurial marketing dimensions (customer orientation, market orientation, entrepreneurial orientation and innovation orientation) have significant relationship with performance measures at 0.01 level of confidence. Hence, MSME performance is affected by entrepreneurial marketing. 
Table 3. Correlation between performance measures and entrepreneurial dimensions.

\begin{tabular}{cccccc}
\hline Test Variables & $\begin{array}{c}\text { Performance } \\
\text { Measures }\end{array}$ & $\begin{array}{c}\text { Customer } \\
\text { Orientation }\end{array}$ & $\begin{array}{c}\text { Market } \\
\text { Orientation }\end{array}$ & $\begin{array}{c}\text { Entrepreneurial } \\
\text { Orientation }\end{array}$ & $\begin{array}{c}\text { Innovation } \\
\text { Orientation }\end{array}$ \\
\hline Performance Measures & 1 & & & & \\
Customer Orientation & $0.488^{* *}$ & 1 & & & \\
Market Orientation & $0.527^{* *}$ & $0.718^{* *}$ & 1 & & \\
Entrepreneurial Orientation & $0.573^{* *}$ & $0.729^{* *}$ & $0.769^{* *}$ & 1 & 1 \\
Innovation Orientation & $0.594^{* *}$ & $0.700^{* *}$ & $0.764^{* *}$ & $0.839^{* *}$ & 1 \\
\hline
\end{tabular}

Note: ${ }^{*}$ Correlation is significant at the 0.01 level (2-tailed).

\section{Analysis of Qualitative Data}

Existing practice of entrepreneurial market in MSME and their overall situation is analyzed on the data obtained though in-depth interview. Further recommendations to improve the MSME performance are also put forward for their growth on the basis of data analysis. The checklist of interview questions was prepared focusing upon some specific issues as existing situation of MSME in Nepal, business performance influencing elements, entrepreneurial marketing practices in Nepalese MSMEs, major problems of Nepalese MSMEs and best ways to improve the MSME performance so that they would be able to contribute for economic generation, employment opportunity and resource utilization in Nepal.

\subsection{Need of Government Support for MSME Development}

Micro Enterprise Development Program (MEDEP) introduced by Nepal government is found effective to develop the confidence of entrepreneurs. In this regard entrepreneur (B) expressed on her own words as "I feel surprise remembering the past that I was lost in Beni bazaar during the first visit. Now, my life has changed. I have regular income and good social relationship after establishing own Allo processing and weaving enterprise with the support from MEDEP".

In contrary, business association executive (E) was not satisfied fully with the presentation of few selected cases of successful entrepreneur in the annual report of government and non-government organization and he put stress to replicate the successful programs within the all regions of the country intensively. He highlighted the requirement of enterprise support program with an example of tooth pick industry. Nepal has been importing tooth pick from China but bamboo trees as the raw material of tooth pick are lying in every geographical region of country without their proper utilization. Similarly, farmers are being suffered due to the unavailability of proper market for their products like ginger and such other crops. Similarly, government executive (A) was worried that hundreds of youth are flying o overseas for employment but government is not able to attract them for self-employment staying together with their family within the country. Association executive (A) tells the need of enterprise friendly policy "the first 
step of Nepal government for enterprise development is to make the simplicity on business registration process and revenue payment system with one window policy system."

Association executive (D) gives importance on enterprise friendly policy that government should full its commitment for industrial development through promotion of micro and small enterprises. The enthusiasm of the entrepreneurs should be promoted instead of discouraging them through long and complicated government procedures to register business and paying tax. Just delivery of speech by leader doesn't work until its effective implementation does not happen. Transparency and accuracy on policy and proper implementation is essential.

\subsection{Entrepreneurial Marketing Practices in Nepalese MSMEs}

Association executives (B and C) summarized that marketing practice is changing due to the globalization and use of internet in business. The traditional marketing is being adopted by large scale enterprises where as entrepreneurial marketing is suitable in small enterprise that are lacking resources and major marketing decisions are influence by an entrepreneur. However, small enterprises have scope to adopt the flexibility as accordance to the changing marketing environment. Major findings of the study show that salesmanship plays vital role for selling the products. The study reveals that Nepalese MSME use pushing strategy of selling their products, word of mouth promotion, buyers' reference, sample distribution, trial taste, door to door visit, TV advertisement, radio ads, print ads, publication, coupons, prize, verbal presentation, hording board, social networking, relationship and internet marketing. Prevailing situation of syndicate and cartel dominated market is undesirable to the society. Quality assurance department and other concern authorities of Nepal government should monitor the market and control the unsystematic price fixing practice, marketing the duplicate goods and transaction of unauthorized goods. The government should ply important role of an umpire where seller and buyers are the key players of marketing game.

\subsection{Need of Motivational Inputs to Youth for Starting Their Enterprise}

Even though involvement in social association is a best way for expanding networking and relationship but least attention on business professionalism may affect negatively to the growth of business in the competition. Entrepreneur (C) presents current trend of MSME owners for being involved in social clubs as path way for political career and being safety from the pressure of donation. $\mathrm{He}$ states "some people have been associated with social clubs and business association for their name, fame and social prestige. Social service, volunteerism and public welfare are being slogan of NGOs and they are interested to visit abroad. Social phenomenon is giving pressure to be associated with political parties so that they could be protected from pressure of donation and demand of different types of gangs". 
In this regard, government executive (A) opinions that youth should be attracted to establish enterprise and they should be provided different training to develop their technical and managerial skills. Proper counseling on cost benefit analysis, opportunity identification, career aspiration and charming of being social contributor would be the important contents of motivational sessions.

\subsection{Infrastructure Facility and Honesty of Political Leaders Is Essential}

Infrastructure facility with road and regular supply of electricity is essential to succeed MSMEs in competitive environment. Entrepreneur (A) assumes the Terai region is the best place to establish enterprise by considering the easy accessibility of raw materials and transportation facility. Entrepreneurs have to face different hurdles to fulfill requirement for registration and tax clearance. Some entrepreneurs have left the business and gone to abroad searching the employment opportunity due to lack of government support. They have to face difficulties acquiring raw materials, finding industrial shed, finding adequate training and such other software and hardware facilities. Government executive (B) gives emphasis for extra duties and taxes for imported goods so that local products can be sold in competitive market. Further, he added "the reasons of failure of privatized industries are weak management, dependency on raw material and undue political influence by the leaders for personal interest. The industrial development programs are to be designed considering the geo-political situation of the country and saying of the late King Prithivi Narayan Shah, Nepal is "Dui Dhunga ko Tarup". It means Nepal has challenge to grow by maintain the balance relationship with neighboring countries, India and China. Similarly, entrepreneur (C) thinks that honesty and sincerity of political leaders, policy makers and government staff is important for developing industrial environment and economic growth of the nation. He says "MSME development is possible by electing honest, sincere and responsible leaders in all levels of government and business association. They should be committed to maintain social harmony and creating self-employment opportunity to the citizens." The government of Nepal should establish industrial village in every province with necessary infrastructure facilities and easy access of loan in cheaper interest rate. Entrepreneur (C) is also assumes the need of financial and technical support adequately and majority of micro and small enterprise owners are not able to utilize their potentialities due to the lack of financial support and risk of competitive market.

On the basis of study result, a model with five dimensions of entrepreneurial marketing is proposed. Influence orientation is newly proposed dimensions over existing four dimensions as market orientation, customer orientation, entrepreneurial orientation, innovation orientation. In this regard, entrepreneurs should possess influencing and persuasion skills to convince government authorities for grabbing opportunities and making them to decide in favor of enterprises. All together 14 elements under five dimensions of entrepreneurial marketing are 


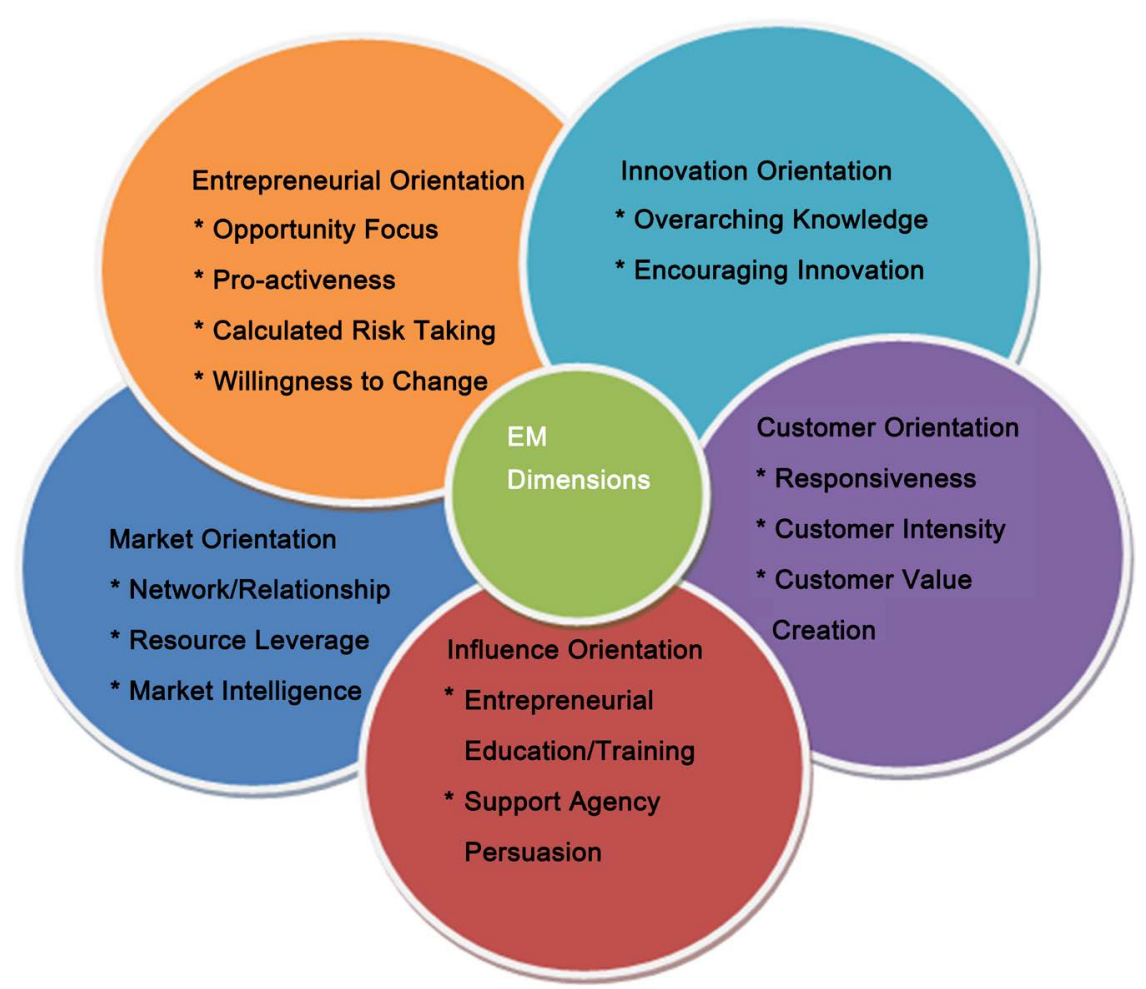

Sources: Five dimensional model of Entrepreneurial Marketing (proposed on the basis of study).

Figure 3. Entrepreneurial marketing model: five dimensions of MSME performance.

identified as significant elements. Entrepreneurial orientation includes four elements named opportunity focus, proactiveness, calculating risk taking and willingness to change. Innovation orientation comprises two elements as overarching knowledge and encouraging innovation. Market orientation includes networking/relationship, resource leverage and market intelligence. Customer orientation has three elements as responsiveness, customer intensity and customer value creation. Newly identified dimension named influence orientation comprises two elements as entrepreneurial education/training and support agency persuasion. Proposed five dimensional model of entrepreneurial marketing is presented in Figure 3.

\section{Conclusions and Suggestions}

Four entrepreneurial marketing dimensions are customer orientation, market orientation, entrepreneurial orientation and innovation orientation [10]. The literature supports that these elements have significant influence on MSME performance. Hypotheses test result of this study also supports the previous findings. Chi-square test, ANOVA analysis and correlation assessment have proved that four dimensions of entrepreneurial marketing as mentioned earlier have significant impact on MSME performance in Nepal.

Qualitative analysis on the basis of in-depth interview identified the prevailing situation of MSME and the best direction for their better performance. Poor industrial policy and ineffective implementation of enterprise development program 
is one of the barriers of MSME failure. Undue political influence and bureaucratic hurdles are observed. Lack of entrepreneurial motivating training and education are observed as the key factors for slow growth of MSME. Long hour electricity load shading and poor infrastructure facility would be the reasons for being unable to serve goods and services in competitive price.

Essential actions that should be adopted to improve MSME performance are enterprise support system, one window tax policy and simple bureaucratic process. Entrepreneurial education and motivational training are essential. Further research is recommended with five dimensions of entrepreneurial marketing in wider geographical region with large number of sample respondents as this study is limited within the Dhaulagari Zone of Nepal. Enterprise friendly bureaucratic system is to be practiced to promote MSMEs in Nepal as this sector can contribute significantly for income generation and employment opportunity in both rural and urban communities of Nepal.

\section{Conflicts of Interest}

The authors declare no conflicts of interest regarding the publication of this paper.

\section{References}

[1] Cacciolatti, L. and Lee, S.H. (2015) Entrepreneurial Marketing for SMEs. Palgrave Macmillan.

[2] Inan, G.G. and Kop, A.E. (2018) Marketing Capability Development in Micro Manufacturing Enterprises. American Journal of Industrial and Business Management, 8, 1-12. https://doi.org/10.4236/ajibm.2018.81001

[3] Kangasmaki, M. (2014) Planning and Implementation of Entrepreneurial Marketing Process in SMEs. Masters' Thesis, Lappeenranta University of Technology.

[4] Rauch, A., Wiklund, J., Lumpkin, G.T. and Frese, M. (2009) Entrepreneurial Orientation and Business Performance: An Assessment of Past Research and Suggestions for the Future. Entrepreneurship Theory and Practice, 33, 761-787.

https://doi.org/10.1111/j.1540-6520.2009.00308.x

[5] David, C. (1990) Some Exploratory Models for Assessing Small Firms' Marketing Performance: A Qualitative Approach. European Journal of Marketing, 24, 8-51. https://doi.org/10.1108/03090569010006056

[6] Igbaekemen, G.O. (2014) Marketing Intelligence as a Strategic Tool for Competitive Edge. British Journal of Marketing Studies, 2, 17-34.

[7] Collinson, E.M. and Shaw, E. (2001) Entrepreneurial Marketing: A Historical Perspective on Development and Practice. Management Decision, 39, 761-767. https://strathprings.strath.ac.uk/4514

[8] Janet, M. and Ngugi, K. (2014) Influence of Entrepreneurial Marketing on the Growth of SMEs in Kiambu Town-CBD, Kenya. European Journal of Business Management, 1, 361-377. https://pdfs.semanticscholar.org/c010/78ca767327582aac36e2a87a2d360ab3e695.pdf

[9] Kurgun, H., Bagiran, D., Qzeren, E. and Maral, B. (2011) Entrepreneurial Marketing-The Interface between Marketing and Entrepreneurship: A Qualitative Research on Boutique Hotels. European Journal of Social Science, 26, 340-357. 
[10] Jones, R. and Rowley, J. (2011) Entrepreneurial Marketing in Small Businesses: A Conceptual Exploration. International Small Business Journal, 29, 25-36. https://www.researchgate.net/publication/254108072_Entrepreneurial_marketing_i n_small_businesses_A_conceptual_exploration https://doi.org/10.1177/0266242610369743

[11] Regmi, N. (2016) Rural Tourism in Nepal: Development and Sustainability: A Case Study of Parbat District. Bachelor's Thesis, Central University of Applied Science.

[12] Nepal Government (2016) Industrial Enterprise Act 2016. Ministry of Law, Justices and Parliament, Kathmandu.

[13] Pokhrel, K.P., Ale, G. and Raut, A. (2018) Polycentric Settlement as a Sustainable Development Strategy: A Case of Baglung District, Nepal. The Geographical Journal of Nepal, 11, 137-155. https://doi.org/10.3126/gjn.v11i0.19554

[14] District Development Committee Myagdi (2013) District Transport Master Plan. District Development Committee, Myadgi.

[15] Gorica, K. and Buhaljoti, A. (2016) Entrepreneurial Marketing: Evidence from SMEs in Albania. American Journal of Marketing Research, 2, 46-52.

[16] Gupta, R. (2012) Role of Strategic and Entrepreneurial Orientation in the Growth of SMEs. Doctoral Dissertation, University of Delhi, Delhi.

[17] Marcati, A., Guido, G. and Peluso, A.M. (2010) What Is the Marketing for SME Entrepreneurs? The Need to Market the Marketing Approach. Journal of Marketing Trends-Small and Medium Enterprises, 1, 67-74.

[18] Saeedikia, M. (2007) Principles of Entrepreneurship. Kia Publications, Tehran.

[19] Moghimi, M. and Dariani, M.A. (2008) The Entrepreneurial Training of Small and Medium-Sized Businesses: Needs and Solutions. Journal of Entrepreneurship Development, 1, 207-245.

[20] Jalilian, K., Jamshidinavid, B. and Ghanbary, M. (2013) The Impact of Entrepreneurial Orientation and Market Orientation on the Performance of Industrial Firms Listed in Tehran Stock Exchange (Food, Chemical, Pharmaceutical, Automobile). International Research Journal of Applied and Basic Sciences, 5, 644-649.

[21] Morris, M.H., Schindehutte, M. and LaForge, R.W. (2002) A Construct for Integrating Emerging Entrepreneurship and Marketing Perspectives. Journal of Marketing Theory and Practice (Fall), 10, 1-19. https://www.researchgate.net/publication/257926297

[22] Gyanwali, M. (2018) SME Growth in a Recession. Doctoral Dissertation, University of Leicester, Leicester.

[23] Mugambi, E.N. and Karugn, W.N. (2017) Effect of Entrepreneurial Marketing on Performance of Real Estate Enterprise: A Case of Optiven Limited in Nairobi, Kenya. International Academic Journal of Innovation, Leadership and Entrepreneurship, 2, 26-45.

[24] Gautam, P.R. (2016) Entrepreneurial Orientation and Business Performance of Handicraft Industry: Study of Nepalese Handicraft Enterprises. International Journal of Small Business and Entrepreneurship Research, 4, 48-63.

[25] Pant, S.K. (2015) Role of the Family in Entrepreneurship Development in Nepali Society. The Journal of Nepalese Business Studies, 9, 37-47.

[26] Kilenthong, P., Hills, G.E. and Hultman, C.M. (2015) An Empirical Investigation of the Entrepreneurial Marketing Dimensions. Journal of International Marketing Strategy, 3, 1-18.

[27] Kaur, K. (2011) Entrepreneurial Orientation: Role of Parenting, Personality and 
Entrepreneurial Exposure. Doctoral Dissertation, Punjab University. http://shodhganga.inflibnet.ac.in

[28] Hills, G.E., Hultman, C.M. and Miles, M.P. (2008) The Evolution and Development of Entrepreneurial Marketing. Journal of Small Business Management, 46, 99-112. https://doi.org/10.1111/j.1540-627X.2007.00234.x

[29] Stewart, E. and Ranis, G. (1990) Macro-Policies for Appropriate Technology: A Synthesis of Findings. In: Stwart, F., Thomas, H. and De Wilde, T., Eds., The Other Policy: The Influence of Policies on Technology Choice and Small Enterprise Development, Intermediate Technology Publications, London, 3-42.

https://www.cabdirect.org/cabdirect/abstract/19901877312 https://doi.org/10.3362/9781780442952.001

[30] Hansen, G.S. and Wernerfelt, B. (1989) Diterminants of Firm Performance: The Relative Importance of Economic and Organizational Factor. Strategic Management Journal, 10, 399-411. https://doi.org/10.1002/smj.4250100502 